\title{
Against the tide
}

\author{
Gaetano Rocco, MD, FRCSEd
}

\footnotetext{
From the Division of Thoracic Surgery, Thoracic Department, Istituto Nazionale Tumori, IRCCS, Fondazione G. Pascale, Naples, Italy.

Disclosures: Author has nothing to disclose with regard to commercial support.

Received for publication Oct 24, 2017; accepted for publication Oct 27, 2017; available ahead of print Nov 29, 2017.

Address for reprints: Gaetano Rocco, MD, FRCSEd, Division of Thoracic Surgery, Thoracic Department, Istituto Nazionale Tumori, IRCCS, Fondazione G. Pascale, Via Semmola 81, 80131 Naples, Italy (E-mail: g.rocco@ istitutotumori.na.it).

J Thorac Cardiovasc Surg 2018;155:1823-4

$0022-5223 / \$ 36.00$

Copyright (C) 2017 by The American Association for Thoracic Surgery

https://doi.org/10.1016/j.jtcvs.2017.10.120
}

Although the methods and the results seem to flow against the tide of the current literature, ${ }^{1}$ the article by Zheng and colleagues $^{2}$ published in this issue of the Journal has several merits. In fact, multidisciplinary teams, especially in North America, tend to consider primary treatment for locally advanced non-small cell lung cancer as nonsurgical, although N2 disease is being resected worldwide for various indications. ${ }^{3}$ In this setting, a list of the important issues that have been raised by the contribution by Zheng and colleagues ${ }^{2}$ can be identified.

First, avoid preresection mediastinal exploration. In this series, patients underwent resection on the basis of evidence of mediastinal involvement at computed tomographic imaging, with positron-emission tomography reserved for bulky $\mathrm{N} 2$ disease. In fact, mediastinoscopy, endobronchial ultrasound, and endoscopic ultrasound were not used to stage the mediastinum of surgical candidates. The concept of avoiding preresectional mediastinal exploration to proceed directly to complete nodal dissection during primary surgery has already emerged in the literature after decades when meticulous mediastinal (invasive) staging has been required to avoid surgery. ${ }^{4}$ Because of this lack of imaging, complete nodal dissection is a crucial component of the upfront surgical approach, especially when the nonnegligible prevalence of $\mathrm{N} 2$ disease in patients with $\mathrm{T} 1$ disease is considered. $^{2}$

Second, use surgery first, but not surgery alone. In the interpretation of outcomes originating from upfront resection for $\mathrm{N} 2$, one misunderstanding is that surgery should be performed as the only therapeutic modality. This series by Zheng and colleagues ${ }^{2}$ clearly shows that surgery should be rather followed by adjuvant treatment, even if it may be difficult to separate the relative impacts of each modality on overall and progression-free survivals. In this context, the impact of the surgical arm in multimodality treatment trials has been recently emphasized, paving the way to considering upfront surgery. ${ }^{5}$ Moreover, recent evidence demonstrates that chemotherapy is the adjuvant treatment of choice after complete resection of unsuspected N2 disease,

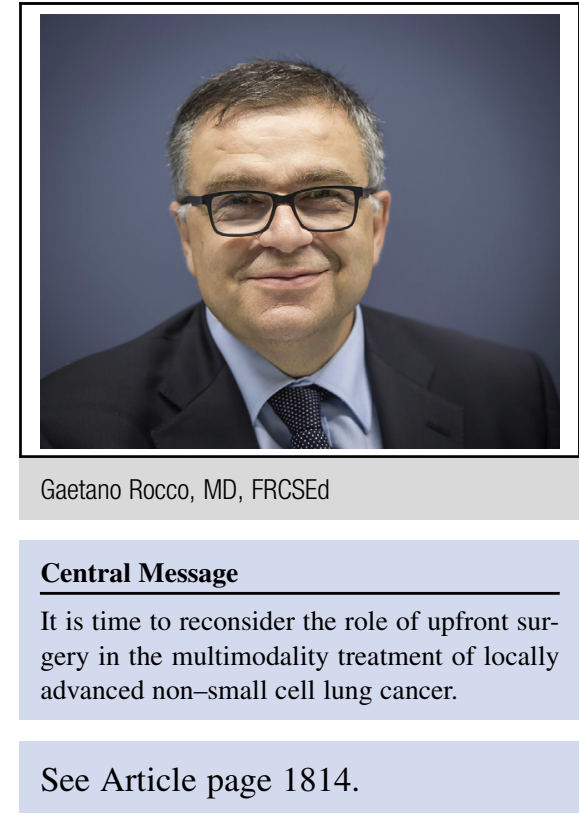

because radiotherapy was not associated with a survival benefit. $^{6}$

Third, lymphadenectomy is linked to survival. Zheng and colleagues ${ }^{2}$ have reported on a large series of patients with primarily resected clinical stage IIIA disease, confirming Liang and colleagues' finding that improved survivals may be related to removing at least 16 lymph nodes per patient ${ }^{7}$ - in the series of Zheng and colleagues, ${ }^{2}$ an average of 20 per patient. Although the thoracic surgical community still lives in the aftermath of the results from American College of Surgery Oncology Group Z0030, which clearly argue against any survival improvement associated with complete lymphadenectomy, ${ }^{8}$ the article by Zheng and colleagues ${ }^{2}$ is an invitation to reconsider the role of surgery as a means of effecting optimal staging and potentially improving survival of patients with lung cancer.

Finally, N2 subsets are associated with survival. Zheng and colleagues' series ${ }^{2}$ confirms the recurring reports in the literature demonstrating the particularly favorable prognostic outlook associated with either occult or single-station N2 subsets. ${ }^{9-11}$ In the article by Zheng and colleagues, ${ }^{2}$ these $\mathrm{N} 2$ subgroups were associated with overall and progression-free survivals in excess of $50 \%$ and $25 \%$, respectively. Moreover, when one considers the whole pIIIA-N2 group, the median progression-free survival of 17.0 months (14 months for cN2) and the median overall survival of 44.0 months (35 months for cN2) should suggest a careful reevaluation of the multimodality 
strategy to be used in patients with N2 non-small cell lung cancer. $^{2}$

Although the limitations of this study are manifold and have been adequately presented by Zheng and colleagues ${ }^{2}$ themselves, the value of this contribution remains significant, inasmuch as it shines a new light on the important role of surgery in the management of locally advanced lung cancer. In this setting, the analysis of the resected mediastinal nodes may also add important information on the immunohistochemical profile of the tumor, thus contributing to finalizing the prognostic outlook. ${ }^{12}$ In a time when old standards of care in oncology are being questioned, ${ }^{13}$ thoracic surgeons should be ready to swim against the tide to propose and collaborate on new clinical trials focused on primary surgery for locally advanced lung cancer.

\section{References}

1. Evison M, Clive A, Castle L, Powell H, Thomas R, Buttery R, et al. Resectable clinical N2 non-small cell lung cancer; what is the optimal treatment strategy? An update by the British Thoracic Society Lung Cancer Specialist Advisory Group. J Thorac Oncol. 2017;12:1434-41.

2. Zheng D, Ye T, Hu H, Zhang Y, Sun Y, Xiang J, et al. Upfront surgery as first-line therapy in selected patients with stage IIIA non-small cell lung cancer. J Thorac Cardiovasc Surg. 2018;155:1814-22.e4.

3. Rocco G, Nason K, Brunelli A, Varela G, Waddell T, Jones DR. Management of stage IIIA (N2) non-small cell lung cancer: a transatlantic perspective. J Thorac Cardiovasc Surg. 2016;15:1235-8.

4. Lim E, McElnay PJ, Rocco G, Brunelli A, Massard G, Toker A, et al. Invasive mediastinal staging is irrelevant for PET/CT positive N2 lung cancer if the primary tumour and ipsilateral lymph nodes are resectable. Lancet Respir Med. 2015;3:e32-3.

5. McElnay PJ, Choong A, Jordan E, Song F, Lim E. Outcome of surgery versus radiotherapy after induction treatment in patients with $\mathrm{N} 2$ disease: systematic review and meta-analysis of randomised trials. Thorax. 2015;70:764-8.

6. Sun JM, Noh JM, Oh D, Kim HK, Lee SH, Choi YS, et al. Randomized phase II trial comparing chemoradiotherapy with chemotherapy for completely resected unsuspected N2-positive non-small cell lung cancer. J Thorac Oncol. September 28, 2017 [Epub ahead of print].

7. Liang W, He J, Shen Y, Shen J, He Q, Zhang J, et al. Impact of examined lymph node count on precise staging and long-term survival of resected non-small-cell lung cancer: a population study of the US SEER database and a Chinese multiinstitutional registry. J Clin Oncol. 2017;35:1162-70.

8. Darling GE, Allen MS, Decker PA, Ballman K, Malthaner RA, Inculet RI, et al. Randomized trial of mediastinal lymph node sampling versus complete lymphadenectomy during pulmonary resection in the patient with N0 or N1 (less than hilar) non-small cell carcinoma: results of the American College of Surgery Oncology Group Z0030 trial. J Thorac Cardiovasc Surg. 2011;141: 662-70.

9. Patterson GA, Piazza D, Pearson FG, Todd TR, Ginsberg RJ, Goldberg M, et al. Significance of metastatic disease in subaortic lymph nodes. Ann Thorac Surg. $1987 ; 43: 155-9$.

10. Riquet M, Bagan P, Le Pimpec Barthes F, Banu E, Scotte F, Foucault C, et al. Completely resected non-small cell lung cancer: reconsidering prognostic value and significance of N2 metastases. Ann Thorac Surg. 2007;84:1818-24.

11. Yoshino I, Yoshida S, Miyaoka E, Asamura H, Nomori H, Fujii Y, et al. Japanese Joint Committee of Lung Cancer Registration. Surgical outcome of stage IIIA$\mathrm{cN} 2 / \mathrm{pN} 2$ non-small-cell lung cancer patients in Japanese lung cancer registry study in 2004. J Thorac Oncol. 2012;7:850-5.

12. Keller MD, Neppl C, Irmak Y, Hall SR, Schmid RA, Langer R, et al. Adverse prognostic value of $\mathrm{PD}-\mathrm{L} 1$ expression in primary resected pulmonary squamous cell carcinomas and paired mediastinal lymph node metastases. Mod Pathol. September 8, 2017 [Epub ahead of print].

13. Antonia SJ, Villegas A, Daniel D, Vicente D, Murakami S, Hui R, et al; PACIFIC Investigators. Durvalumab after chemoradiotherapy in stage III non-small-cell lung cancer. N Engl J Med. 2017;377:1919-29. 